міжнародних договорів або імплементації актів міжнародних організацій взаємодія держав-учасниць спільного ринку, спрямована на досягнення схожого або однакового регулювання трудових відносин.

\title{
Література:
}

1. Рим О. М. Виникнення та розвиток трудового права Європейського Союзу. Вісник Львівського торговельно-економічного університету. Юридичні науки. 2018. Вип. 7. С. 297-306.

2. Baden-Baden: Nomos Verlagsgesellschaft : München : Verlag C. H. Beck : Oxford, United Kingdom : Hart Publishing, 2018. 209 p.

3. Терлецький Д. С. Трансформація, інкорпорація та імплементація норм міжнародного права: теоретичний аналіз. Молодий вчений. 2017. Лип. № 7 (47). С. 395-400.

4. Конституція України: Закон від 28.06.1996 № 254к/96-ВР. База даних «Законодавство України» / ВР України. URL: https://zakon.rada.gov.ua/laws/show/254\%D0\%BA/96-\%D0\%B2\%D1 \%80\#Техt (дата звернення: 17.01.2021).

5. Правова система України: історія, стан та перспективи: в 5 т. / за заг. ред. М. В. Цвіка, О. В. Петришина. Харків, 2008. Т. 1: Методологічні та історико-теоретичні проблеми формування та розвитку правової системи України. 728 с.

6. Давид Р., Жоффре-Спинози К. Основные правовые системы современности / пер. с фр. В. А. Туманова. Москва, 1999. 400 с.

DOI https://doi.org/10.30525/978-9934-26-074-2-25

\section{ШТУЧНИЙ ІНТЕЛЕКТ І ТРУДОВІ ВІДНОСИНИ: ВПЛИВ І ВЗАСМОДІЯ}

\author{
Гущу С. Ф. \\ orcid.org/0000-0003-1373-6079 \\ кандидат юридичних наук, доцент, \\ дочент кафедри права \\ гуманітарно-правового факультету \\ Національного аерокосмічного університету імені М. С. Жуковського \\ «Харківський авіаційний інститут» \\ м. Харків, Україна
}

Впровадження штучного інтелекту в економічні і соціальні процеси безумовно впливають на відносини між працівником і роботодавцем. 
Самі ці відносини залежать від типу економіки і рівня розвитку економічних відносин в суспільстві. Наразі є актуальним не так питання чи впливає штучний інтелект на зміну типу і змісту трудових відносин, а питання як саме вони змінюються i які модернізації трудового законодавства потребують.

Аналіз наукової літератури і статистичних досліджень дозволяє говорити про те, що більшість фахівців - юристів, економістів, соціологів підтримують точку зору про те що насьогодні в сфері трудових відносин відбуваються серйозні трансформації у зв'язку з цифровізацією суспільства. Дослідження А. Корінека, М. Вебб показують наскільки впровадження штучного інтелекту впливає на зменшення робочих місць, на переваги роботів перед людиною в сфері ефективності на здешевлення виробництва [1], [2]. Викликають інтерес праці І.А. Філіпової, яка вважає, що в умовах цифровізації: «Право буде змушене піддатися коригуванню, щоб зберегти ефективність правового регулювання» [3]. Серед українських дослідників правового визначення штучного інтелекту привертають увагу праці Баранова О.А., Харитонова Є., Харитонової О., Радутного О.Е., але вплив впровадження роботів і технологій на трудові відносини у вітчизняній науковій літературі залишаються поза увагою більшості науковців.

Процес переходу суспільства від індустріальної економіки до цифрової значно змінює зміст і форму трудових відносин. Впровадження технологій штучного інтелекту у виробництво і сервіс поступально підвищує рівень їх автоматизації: зростають обсяги застосування складного програмного забезпечення і роботизованих систем, що призводить до зміни в організації найманої праці. Серед нових умов, на які не розраховане чинне трудове законодавство: заміна працівників на робочих місцях робототехнікою, значна зміна функціоналу працівника в зв'язку з автоматизацією виробництва, поширення нетипових форм зайнятості.

2 грудня 2020 року Кабінет Міністрів України схвалив Концепцію розвитку штучного інтелекту в Україні. Цей документ $є$ відправною точкою в нашому законодавстві для подальшої трансформації трудового права в умовах розвитку Індустрії 4.0. Важливими новаціями Концепції стало правове визначення терміну «штучний інтелект» [4]. Крім цього, наявність ризиків зростання рівня безробіття у зв 'язку з використанням технологій штучного інтелекту визначено як одну з проблем, яка потребує вирішення. Уряд вважає, що технології штучного інтелекту повинні сприяти трансформації економіки, ринку праці, державних інституцій та суспільства в цілому. Для цього пріоритетними напрямами реалізації Концепції, серед інших, є: 
- підвищення рівня професійної підготовки спеціалістів для забезпечення сфери технологій штучного інтелекту кваліфікованими кадрами;

- приведення законодавства у галузі використання технологій штучного інтелекту у відповідність із міжнародними нормативноправовими актами;

- розроблення Дорожньої карти щодо перекваліфікації людей, робота яких може бути автоматизована в найближчі п’ять - десять років і як наслідок -значне збільшення кількості кваліфікованих спеціалістів у галузі штучного інтелекту, в тому числі наукових та науковопедагогічних працівників, а також поширення серед населення навичок компетентного використання штучного інтелекту.

Таким чином проблема впливу штучного інтелекту на ринок праці та трудові відносини $є$ незаперечним фактом. Нажаль, у вітчизняному законодавстві на сьогодні це єдиний документ, що визначає згадану проблему.

Процеси, пов'язані з цифровізаціею економіки і суспільства в цілому, суттєво впливають на відносини між працівниками та роботодавцями, тому в середовищі наукових дослідників з трудового права, економіки та соціології праці останнім часом все частіше піднімаються питання про те, як саме зміниться регламентація відносин у сфері праці. Популярним $\epsilon$ висновок, що автоматизація скорочує витрати праці і знижує загальний попит на робочу силу, тому в епоху швидкої автоматизації зростає ймовірність погіршення становища працівників [5]. 3 цією позицією важко не погодитись.

Згідно з аналізом компанії PwC [6] штучний інтелект, робототехніка i інші форми інтелектуальної автоматизації можуть принести величезні економічні вигоди, які до 2030 року принесуть до 15 трильйонів доларів у світовій ВВП. Очікування таких прибутків також створить попит на багато робочих місць, але $\epsilon$ також побоювання, що вони можуть витіснити багато існуючих робочі місця. До середини 2030-х років до $30 \%$ робочих місць можна буде автоматизувати.

Згідно з доповіддю UNCTAD ключовими змінами ринку праці стануть:

- поява нових робочих місць і професій (в сферах електронної комерції, 3D друку, програмного забезпечення, кібер-безпеки і т.д.);

- зникнення ряду колишніх професій;

- зміна умов праці (збільшення обсягу вилученої роботи, роботи через інтернет-платформи, зростання частки прекаріата через зниження рівня соціального захисту працівників); 
- збільшення частки праці, що вимагає цифрових навичок (digital skills) [7].

Європейський фонд поліпшення умов життя та праці в січні 2020 року опублікував звіт «Технології, що змінюють ігри: трансформація виробництва та зайнятості в Свропі», в якому вивчався вплив восьми факторів (адитивне виробництво, передова робототехніка, Інтернет речей, промислові біотехнології, електромобілі, автономні транспортні засоби, блокчейн та віртуальна та доповнена реальність) у різних секторах економіки. У звіті прогнозуються зміни у промисловості, послугах, ринку праці та зайнятості під впливом кожного з восьми факторів [8].

29 серпня 2017 року Департамент з економічних і соціальних питань ООН опублікував дослідження про вплив технологій на ринок праці («Frontier Issues: The impact of the technological revolution on labour markets and income distribution») [9]. Вказане дослідження в області штучного інтелекту також показує, що технології матимуть «величезний вплив» на ринки праці. Якщо прийняти необхідні закони на місцевому, національному та міжнародному рівнях, цей вплив можна буде направити в позитивне русло. Зокрема, зазначається що нові технології замінюють не цілі професії, а конкретні завдання. Технологічні зміни змінюють попит на навички на ринку праці i, щоб залишатися конкурентоздатними на робочих місцях, які доповнюються штучним інтелектом, робітники повинні набути необхідних навичок під час їх утворення або під час професійного навчання. Надання відповідних навичок робітникам - важлива область державної політики. Поставки робочої сили на кожному рівні кваліфікації залежить від системи освіти і професійного навчання.

Необхідність у побудові нової системи професійного навчання i підвищення цифрових навичок працівників - ідея не нова. Ці питання неодноразово піднімалися як у дослідженнях незалежних організацій, так i на рівні регіональних i міжнародних інституцій. Окремі країни $\mathrm{i}$ організації мають позитивний досвід в запровадженні програм навчання працівників. Цей досвід ми вивчали і аналізували у своїх минулих працях [10]. Не можна забувати і про рівень конкурентоздатності штучного інтелекту перед людиною, що також потребує перегляду і нового визначення змісту деяких принципів трудового права.

Отже, розвиток штучного інтелекту і впровадження його в усі сфери виробництва потребує суттєвої трансформації трудового права. В першу чергу - в сфері змінення змісту і форм трудових правовідносин, в напрямі організації безперервного навчання та перекваліфікації 
працівників, розширення використання нетипових форм зайнятості, забезпечення принципів рівності і безпеки праці.

\section{Література:}

1. Korinek A. Labor in the age of automation and artificial intelligence. Available at: https://econfip.org/wp-content/uploads/2019/02/6.Labor-in-theAge-of-Automation-andArtificial-Intelligence.pdf

2. Webb M. The impact of artificial intelligence on the labor market. 2020. Available at: https://web.stanford.edu/ mww/webb_jmp.pdf

3. Filipova I.A. (2020) Labour Law: Challenges of Digital Society. Pravo. Zhurnal Vysshey shkoly ekonomiki, no 2, pp. 162-182 (in Russian)

4. Концепція розвитку штучного інтелекту в Україні. Режим доступу: https://zakon.rada.gov.ua/laws/show/1556-2020-\%D1\%80\#Text .

5. Acemoglu D., Restrepo P. The wrong kind of AI? Artificial intelligence and the future of labor demand. Available at: https://www.nber.org/papers/w25682.pdf

6. How will automation impact jobs? Available at: https://www.pwc.co.uk/services/economics/insights/the-impact-of-automationon-jobs.html?utm_campaign=sbpwc\&utm_medium=site\&utm_source $=$ articletext\#data-explorer.

7. Information economy report 2017: Digitalization, trade and development. United Nations Conference on trade and development. Sales No. E.17.II.D.8. (2017). P. 62.

8. Game-changing technologies: Transforming production and employment in Europe», Eurofound, 2020, Publications Office of the European Union, Luxembourg. Available: https://www.eurofound.europa.eu/ de/publications/report/2020/game-changing-technologies-transformingproduction-and-employment-in-europe\#tab-01.

9. United Nations Department of Economic and Social Affairs, (2017). The impact of the technological revolution on labour markets and income distribution. Available at: https://www.un.org/development/desa/dpad/ publication/frontier-issues-artificial-intelligence-and-other-technologies-willdefine-the-future-of-jobs-and-incomes/.

10. Гуцу С.Ф. Вплив Індустрії 4.0 на трудові відносини і ринок праці: Міжнародний досвід для України// Науковий Вісник Ужгородського Національного університету. Серія ПРАВО Випуск 61 - Том 1. - 2020. - C. 101-106. http://visnyk-juris-uzhnuuz.com/61-tom-1. 